\title{
Marketisation in China Progress and contribution to growth
}

\author{
Xiaolu Wang, Gang Fan and Hengpeng Zhu
}

China has persevered in its market-oriented economic reform for nearly 30 years. Guided by a reform strategy of 'groping for stones to cross the river', China managed to avoid major economic decline and the crises that occurred in other transitional economies such as Russia and Eastern European countries. It successfully transformed the previously centrally planned economy into a mainly market-oriented economy with continued rapid growth, although there are still many conflicts between the new and the old systems.

\section{Progress in marketisation}

As indicated in the NERI Index of Marketisation for China's Provinces, newly published by the National Economic Research Institute (NERI) (Fan et al. 2007), China has achieved significant marketisation since its WTO accession in 2001. Measured by a zero to 10 score system for the base year (2001), the average score for marketisation of China's 31 provinces (including five autonomous minority ethnic regions and three municipalities directly under the control of the central administration) increased 1.88 in the four years from 2002-05, to reach 6.52 in 2005. Thirty provinces out of the total of 31 made positive progress (Figure 3.1). In comparison, the average score of marketisation increased only 0.61 in the previous four years from 1998-2001.

The NERI index is an assessment system for relative progress in marketisation for China's provinces using a comparative method. Marketisation is assessed in five fields by a total of 23 basic indicators. Data are either from statistics or enterprise and household surveys. The NERI index is now available for the 
Figure 3.1 NERI index for progress in marketisation in China's provinces, 2001 and 2005

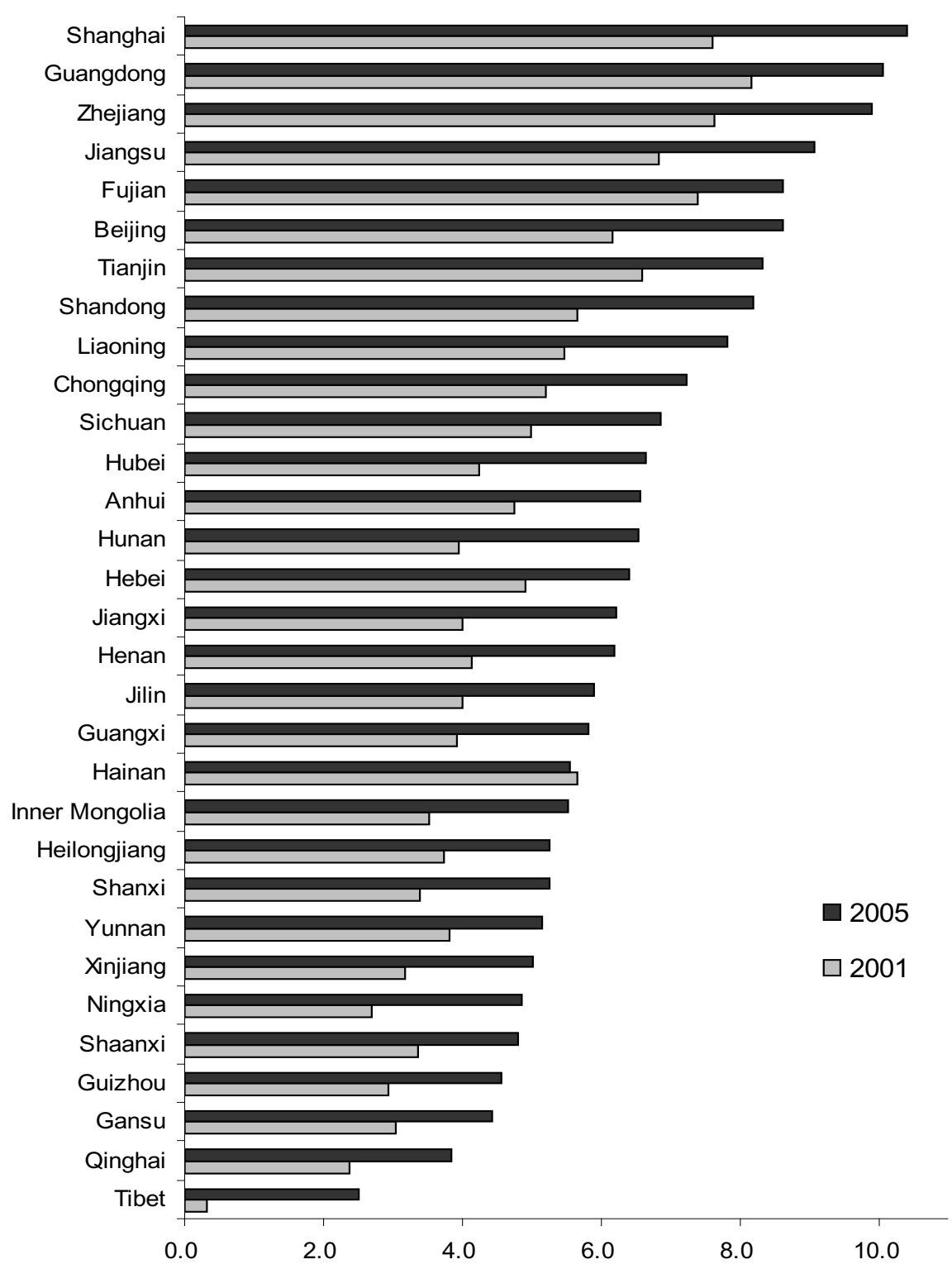

Source: Fan, G., Wang, X. and Zhu, H., 2007. NERI Index of Marketisation for China's Provinces: 2006 report (in Chinese), Economic Science Press, Beijing. 
years from 1997 to 2005. Four reports have been published (Fan and Wang 2001; Fan et al. 2003, 2004, 2007). A map of China shows the relative achievements of China's provinces in marketisation in 2005 (Figure 3.2).

In this index system, each of the 23 indicators is normalised into a basic index with a zero-10 relative score system at the base year. For data shown in Figure 3.1, the base year is 2001. The best and worst performing provinces in a particular indicator receive scores of 10 and zero, respectively. Other provinces receive scores in between, according to their performance in this indicator relative to the best and worst performing provinces. For a positively related

\section{Figure 3.2 Marketisation in China, 2005}

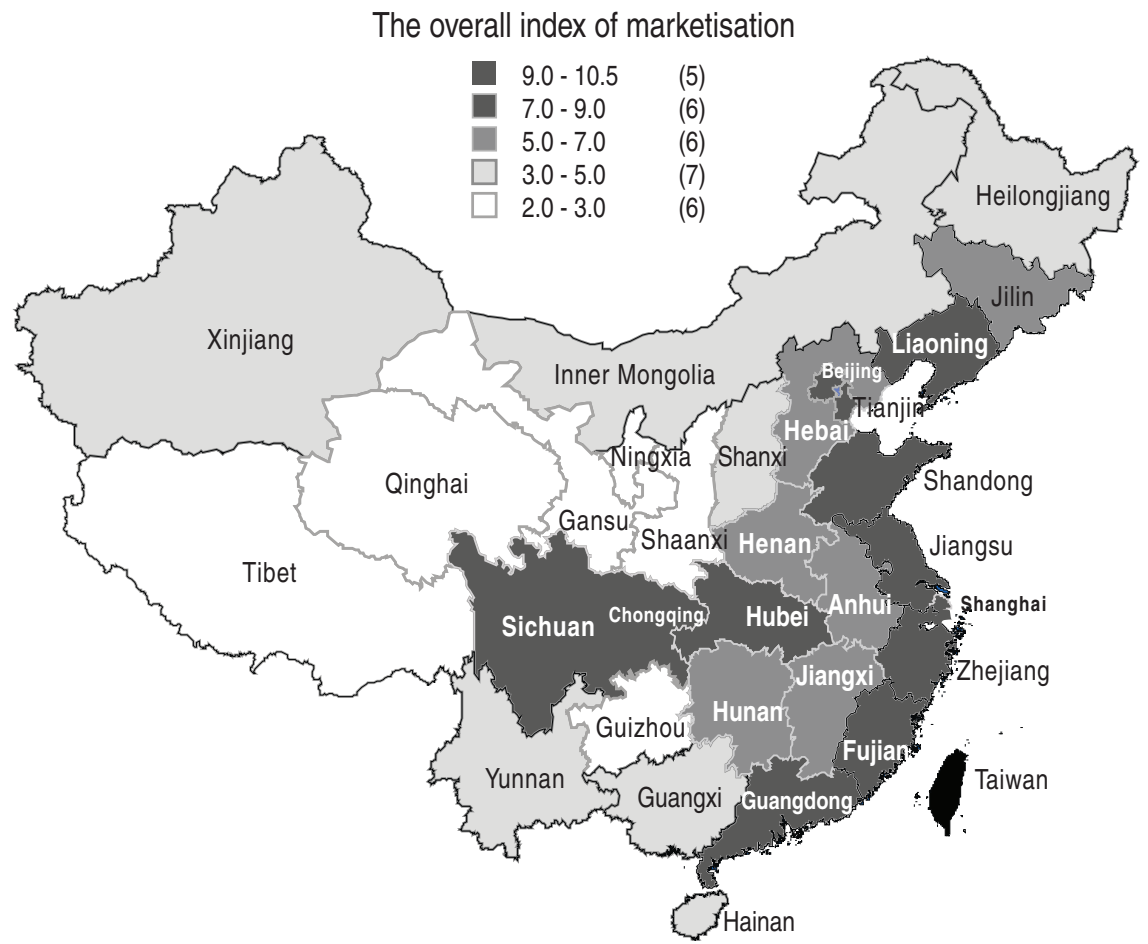

Source: Fan, G., Wang, X. and Zhu, H., 2007. NERI Index of Marketisation for China's Provinces: 2006 report (in Chinese), Economic Science Press, Beijing. 
indicator, for instance, the score of a basic index $j$ for province $i$, noted as $\mathrm{S}_{\mathrm{ij}}$ ' is calculated with the following equation

$$
S_{i j}=\frac{V_{i}-V_{\text {min }}}{V_{\text {max }}-V_{\text {min }}} \times 10
$$

After positive or negative variations over years, a basic index allows a province to have scores above 10 or below zero, so that its progress over time can be measured.

For a certain field-for instance, development of the non-state enterprise sector-a field index is constituted using a few basic indices. A total of five field indices constitute the overall marketisation index. All the field indices are weighted equally in the overall index, as are the basic indices in each field index. ${ }^{1}$

The next section reviews progress in marketisation in China in the five fields as classified in the NERI Index of Marketisation using mainly direct statistical and survey data other than the scores of the index.

\section{Government and market relations}

We measure the level of resource allocation by governments and the market using the share of government budgetary expenses in gross domestic product (GDP). In this measure, the government share was lowered significantly during the reform period, while the market played increasingly important roles in resource allocation. At the national level, the share was 30.8 per cent in 1978 (the first year of economic reform), decreasing to 18.5 per cent in 2005 (the lowest ratio during this period was 11.2 per cent in 1995 and 1996) (National Bureau of Statistics various years). There were slight decreases in this share during the period 2001-05. The budgetary share in GDP is certainly not a linear indicator for marketisation; it will become stable at a certain level after the transitional period. We have found, however, that changes in this share in the past generally related to market-oriented institutional reforms, and provinces with relatively low shares were generally more marketised in different aspects. It is, therefore, still a good indicator, for the time being, to reflect relative changes in the role of governments and the market in resource allocation.

Nevertheless, this is not a full picture for resource allocation between governments and the market, because there is a large amount of non-tax financial collection by different levels of government, which is used outside the budget. Two additional indicators are helpful for these issues. One is the non-tax 
financial burden of enterprises as a proportion of their total sales (data are from enterprise surveys covering about 4,000 enterprises). As a provincial average, the burden fell from 2.8 per cent in 2001 to 1.6 per cent in 2005. Another indicator is farmers' tax and non-tax burdens as a proportion of their per capita income. This fell from 3.6 per cent in 2001 to 0.4 per cent in 2005. Both indicators show improvement in the past four years. In particular, the reduction in the latter share is remarkable, and it resulted mainly from abolition of the agricultural tax and non-tax collections in rural areas.

It is also important to examine the level of government intervention in enterprises. This can be indicated by the survey data on the proportion of entrepreneurs' working time spent dealing with various government departments and their officials (survey data from more than 4,000 enterprises, by NERI). It fell slightly from an average of 18 per cent to 17.2 per cent in the four years covered, but the level of government intervention remains high (Fan et al. 2007).

One indicator shows a worsening situation: the size of government (number of employees) as a share of the total population. At the national level, it increased from 0.86 per cent in 2001 to 0.95 per cent in 2005 (National Bureau of Statistics various years). ${ }^{2}$

The above indicators generally show progress in government-market relations, although they also show that further reform of the government sector is needed, especially to reduce the size of government and to reduce unnecessary government intervention in enterprises.

\section{Development of the non-state enterprise sector}

The non-state enterprise sector is basically the private enterprise sector, which consists mainly of private enterprises, foreign-funded enterprises, shareholding companies and a small number of collectively owned enterprises (in the prereform period, it consisted entirely of collectively owned enterprises).

Development of non-state enterprises made the most remarkable progress among the five fields of marketisation. In the industrial sector in the pre-reform period, state-owned enterprises held a dominant position. The non-state share in gross output value was only 22.4 per cent in 1978, the first year of economic reform. This share increased to 69.2 per cent in 2005. The share of state-owned enterprises shrank from 77.6 per cent to 30.8 per cent during this period (National Bureau of Statistics various years).

In the four years between 2001 and 2005, the non-state share in the industrial sector increased by five percentage points. Meanwhile, the non-state share in total investment in fixed assets increased by 13 percentage points, from 52.6 to 65.6 per cent; and the share of the urban non-state sector in urban 
employment increased by eight percentage points, from 68.1 to 76.3 per cent (Fan et al. 2007).

Data for the non-state share in the services sector are unavailable. The share could be lower than the share in industry, because a few sectors in services are state dominated, including banking, insurance, telecommunications, railways and aviation. Nevertheless, some other services—such as retail sales, catering, road transport and various personal/residential services-are nearly fully privatised. The non-state shares in total investment and urban employment indicate a general situation of non-state domination of the economy.

\section{Development of the commodity market}

In the pre-reform period, prices of most products were controlled by the state. In 2001, the share of prices determined in commodity markets achieved 92 per cent, rising to 92.8 per cent in 2004 (Fan et al. 2007).

During the reform period, most non-tariff trade barriers were removed. The general tariff level reduced substantially before and after WTO accession, from 16.4 per cent in 2000 to 9.8 per cent in 2007 (China Securities Newspaper, 27 December 2006).

Local trade protection was also reduced. The NERI index uses enterprise survey data to show that the score for reducing local trade protection-as an average of the 31 provinces-increased from 6.5 to 9.7 in the 2001-05 period, meaning there was a remarkable reduction in local trade barriers (Fan et al. 2007).

\section{Development of factor markets}

Although the development of factor markets lagged behind that of the commodity market, various indicators show improvement in factor markets in recent years.

For labour market development, the share of rural workers in total urban employment, as a provincial average, increased from 8.1 per cent in 2001 to 11.9 per cent in 2004 (National Bureau of Statistics various years), which indicates increases in labour mobility and reductions in institutional barriers in the labour market. These statistics are likely to be understated due to incomplete data. Some widely accepted estimates suggest that about 100-120 million rural workers work in cities and towns, and possibly 60-100 million work in rural non-agricultural sectors. The next thing to be done is policy restructuring to enable rural migrants to settle in cities and to be treated equally by the urban social welfare systems. 
For development of the financial market, two indicators are important. One is the level of deposits in non-state financial institutions as a share of total deposits in the banking sector, which increased gradually from 32.2 to 36.4 per cent in the four years until 2005. This indicates reductions in the share of state-owned banks, although they remain in a dominant position. Another indicator is the share of bank loans credited to non-state enterprises, which increased from 55.7 to 70.2 per cent during the same period-the latter basically consistent with non-state shares in the industrial sector. This shows significant progress in the commercialisation of the banking sector. State-owned enterprises no longer enjoy the favourable position in obtaining bank loans that they did in the earlier period (Fan et al. 2007).

To indicate development of the technology market, the market transaction value of technologies increased from 2,566 yuan to 4,848 yuan per capita technical personnel during the period from 2001 to 2005. Nevertheless, the latter figure is still low in its absolute value (Fan et al. 2007).

One worsening indicator in this field is foreign direct investment (FDI) as a ratio of GDP. As a provincial average, this ratio decreased from 30.7 to 20.5 (million US dollars per billion yuan of GDP, both in current prices) during the period from 2001 to 2005. This is because GDP is growing faster than FDI, although total FDI is still large. In 2005, FDI was US\$60 billion, but there have been large regional variations. While FDI in the traditional major recipient region, Guangdong Province, is declining, it increased rapidly in the Yangzi River Delta region-that is, in Jiangsu, Zhejiang and Shanghai-and a few other provinces in the coastal and central areas (Fan et al. 2007).

\section{Market intermediaries and the legal environment for the market}

To measure development of market intermediaries, one should consider numbers of independent accountants, lawyers, consultants, chambers of commerce, and other professionals. However, data are available only for independent accountants and lawyers. These two indicators, together as a share in total population, increased slightly during 2001-05. This reflects market development in the current stage because there were no lawyers in the prereform period, and accountants were not independent.

To measure the legal environment for businesses, an available indicator is 4,000 company leaders' judgments collected from enterprise surveys. The average score at the provincial level in the NERI index is generally low, and shows slight deterioration in the legal environment in 2005 from that in 2001 (2.85 for 2005 and 2.88 for 2001). 
To measure protection of intellectual property rights, the only available information is patent applications and grants per technical personnel. These data nearly doubled during the period, showing a rapid improvement.

\section{A general assessment of marketisation in China}

A basic market framework has been established in China. Marketisation has made progress in nearly all fields in recent years. The most remarkable achievement is development of the non-state enterprise sector, which has held the dominant position in the Chinese economy. Development of the commodity market has been relatively rapid, and market competition is now playing a dominant role in industry and trade. Factor markets developed more slowly in general, although they have been making significant progress in recent years.

There are also bottlenecks in market-oriented transformation. Most importantly, institutional and legal frameworks are incomplete and, to some extent, conflict with the market mechanism. There are still unnecessary government interventions, unregulated financial collections and low transparency in administration. The size of government is inflating. The legal environment for the market is still undesirable. These all indicate a need for further institutional change and public sector reform.

At the sector level, the manufacturing sector is now nearly fully marketoriented, whereas marketisation in the financial sector is lagging. A few service sectors are still low in efficiency and lack market competition. Market intermediaries are underdeveloped.

In terms of regional development, the process of marketisation is uneven. While the eastern coastal areas are more marketised than other regions, the achievement of marketisation in some central and western provinces is relatively low. The non-state enterprise sector is underdeveloped in these provinces, and the business climate there is less desirable than elsewhere. In spite of this, the encouraging news is that most provinces made remarkable progress in marketisation in recent years (see Figure 3.1).

\section{Does marketisation contribute to economic growth?}

In this section, we test empirically whether marketisation contributes to China's economic growth at the provincial level, using the NERI Index of Marketisation and a panel data growth model. The NERI index was first established in 2001, and has been updated four times (Fan and Wang 2001; Fan et al. 2003, 2004, 2007). It aims to assess relative achievements in marketisation in China's 31 
provinces. It has so far covered nine years, from 1997 to 2005. Within each of four sub-periods, the scores for each province are comparable not only with other provinces, but over years, so progress in marketisation in each province can be traced. Due to changes in some statistical indicators, however, and modification of the index system, scores were not comparable between different sub-periods.

In this chapter, we convert all the indices into a consistent style: that is, we make all the scores comparable for the whole period from 1997 to 2005 (see Table A3.1 for a consistent version of the NERI Index of Marketisation and Table A3.2 for the whole structure of the NERI index system). This enables us to carry out a panel data analysis to test the contribution of marketisation to China's economic growth. A Solow-type growth model with modification to include a human capital variable (see Solow 1956; Lucas 1988) and a few structural variables - that is, the marketisation index, trade dependency ratio and a regional dummy-is specified as follows

$$
\ln Y_{i t}=C+a_{1} \ln K_{i t}+a_{2} \ln L_{i t}+a_{3} E_{i t}+a_{4} M_{i t}+a_{5} R_{i t}+a_{6} D_{i t}
$$

where $Y$ is provincial GDP in constant prices for year 1990; $K$ is provincial capital stock in 1990 prices; $L$ is provincial employment; $E$ is the average year of schooling of the provincial population; $M$ is the marketisation index; $R$ is the trade dependency ratio (sum of the import and export value as a proportion of GDP) for possible growth effects of economic openness; $D$ is a dummy variable for the coastal areas to catch the geographic differences in initial levels of log GDP ( $\mathrm{D}=1$ for coastal provinces and zero otherwise); and $C$ is the intercept term. The subscripts ${ }_{i}\left({ }_{i}=1 \ldots 31\right)$ and ${ }_{t}\left({ }_{t}=1997 \ldots 2005\right)$ represent provinces and years, respectively.

An earlier version of the model also includes a variable for urbanisation, which is represented by urban share in total employment. A non-positive and insignificant result was derived, probably due to low accuracy of the data (statistical data for rural-urban migrant workers are incomplete). It is therefore omitted from the model.

Data are calculated mainly from provincial statistics from 1997 to 2005 (National Bureau of Statistics 2005b), except the marketisation index. GDP is deflated using the implied GDP deflators from the National Bureau of Statistics. Capital stock is calculated from provincial investment in fixed assets during the 1952-2005 period, using a perpetual inventory method, and is deflated using the price index for investment in fixed assets. ${ }^{3}$ The average year of schooling is calculated from the grouped data for the population at six years old and above 
with the following assumptions: six years of schooling for primary education, nine years for junior secondary education, 12 years for senior secondary education and 16 years for tertiary and postgraduate education. Export and import values are converted into yuan using average exchange rates for the corresponding year. The dummy variable for coastal areas covers the following provinces: Liaoning, Beijing, Tianjin, Hebei, Shandong, Shanghai, Jiangsu, Zhejiang, Fujian, Guangdong and Hainan. Guangxi is excluded because it does not have a major port, and it is customarily not classified as a coastal province.

The model is estimated using fixed-effect and random-effect generalised least squares GLS regressions. The two results are very similar, and the Hausman Test accepts the random-effect regression. The results of the unrestricted model show a nearly perfect nature of constant returns to capital and labour-very close to that of the restricted model. With inclusion of the education variable, the economy shows an increasing return to scale technology, thus indicating a significant contribution of human capital to economic growth (Table 3.1). This could include its direct contribution to growth and possibly a spillover effect.

The marketisation index is positive and significant, indicating an important effect on economic growth (Table 3.1). The trade dependency ratio has a positive, although insignificant, estimate. The growth effect of economic openness is therefore unconfirmed.

In Table 3.2, the contribution of factors to economic growth is calculated based on the estimates of the unrestricted model in Table 3.1. Statistical data for inputs and output are of provincial averages, divided into two sub-periods-that is, 1998-2001 and 2002-05. The table shows that capital growth made a major contribution to economic growth. Education made a 1.3 percentage point contribution to the economic growth rate in the first sub-period, but contributed only 0.4 percentage points in the second sub-period. Marketisation contributed 0.8 percentage point to growth in the first sub-period, but 2.4 percentage points in the second sub-period. This is clear evidence that marketisation has made an important contribution to China's economic growth. The marketisation process was accelerated after China's WTO accession, and has led to significant increases in its contribution to economic growth.

\section{Conclusions}

We have shown that marketisation in China accelerated during the period from 2001 to 2005 - that is, the period after China's WTO accession. The basic framework of a market economy has been established, although there are still 


\section{Table $3.1 \quad$ Estimation results}

\begin{tabular}{lccc}
\hline & $\begin{array}{c}\text { Restricted model } \\
\text { (fixed effect) }\end{array}$ & $\begin{array}{c}\text { Restricted model } \\
\text { (random effect) }\end{array}$ & $\begin{array}{c}\text { Unrestricted model } \\
\text { (random effect) }\end{array}$ \\
InK & 0.5790 & 0.5843 & 0.5900 \\
InL & $\left(20.33^{*}\right)$ & $\left(25.70^{*}\right)$ & $\left(21.49^{*}\right)$ \\
& 0.4210 & 0.4157 & 0.4195 \\
E (year of schooling) & 0.0819 & & $\left(16.70^{*}\right)$ \\
& $\left(5.31^{*}\right)$ & 0.0798 & 0.0782 \\
M (marketisation) & 0.0529 & $\left(6.26^{*}\right)$ & $\left(5.80^{*}\right)$ \\
& $\left(6.54^{*}\right)$ & 0.0518 & 0.0501 \\
R (trade/GDP) & 0.0153 & $\left(7.61^{*}\right)$ & $\left(6.08^{*}\right)$ \\
& $(0.34)$ & 0.0229 & 0.0263 \\
D (coastal dummy) & $($ dropped) & $(0.57)$ & $(0.64)$ \\
& & 0.1193 & 0.1179 \\
C (constant) & -1.1942 & $\left(2.58^{*}\right)$ & $\left(2.58^{*}\right)$ \\
& $\left(10.70^{*}\right)$ & -1.2199 & -1.2716 \\
R2: within & 0.9593 & $\left(-13.06^{*}\right)$ & 0.9590 \\
Between & 0.9882 & 0.9498 & 0.9899 \\
Overall & 0.9850 & 0.9624 & 0.9878 \\
& & 0.9602 & \\
\hline
\end{tabular}

Notes: The numbers in parentheses are ' $z$ ' ratios. Those with * are significant at the 1 per cent level.

Source: Authors' calculations.

\section{Table 3.2 Growth accounting: factor contribution to economic growth}

\begin{tabular}{|c|c|c|c|c|c|}
\hline Coefficient & GDP & $\begin{array}{c}\text { Capital } \\
0.590\end{array}$ & $\begin{array}{l}\text { Labour } \\
0.419\end{array}$ & $\begin{array}{l}\text { Education } \\
0.078\end{array}$ & $\begin{array}{l}\text { Marketisation } \\
0.050\end{array}$ \\
\hline \multicolumn{6}{|c|}{ Annual input-output growth } \\
\hline 1998-2001 (per cent) & 9.8 & 11.3 & -0.2 & 0.161 & 0.153 \\
\hline 2002-05 (per cent) & 12.5 & 14.5 & 1.9 & 0.048 & 0.471 \\
\hline \multicolumn{6}{|c|}{$\begin{array}{l}\text { Contribution to growth rate } \\
\text { (percentage points) }\end{array}$} \\
\hline 1998-2001 & & 6.7 & -0.1 & 1.3 & 0.8 \\
\hline 2002-05 & & 8.6 & 0.8 & 0.4 & 2.4 \\
\hline \multicolumn{6}{|c|}{$\begin{array}{l}\text { Share of contribution } \\
\text { (growth rate }=100 \text { per cent) }\end{array}$} \\
\hline 1998-2001 (per cent) & & 67.8 & -1.0 & 12.8 & 7.8 \\
\hline 2002-05 (per cent) & & 68.5 & 6.2 & 3.0 & 18.9 \\
\hline
\end{tabular}

Notes: Education is measured by annual changes in years of schooling, and marketisation is measured by annual changes in the scores of the NERI Index of Marketisation. Statistics for the GDP growth rate at the provincial level, on average, are higher than at the national level. Sources: Table 3.1 and Table A3.1; National Bureau of Statistics (NBS), various years. China Statistical Yearbook, China Statistical Press, Beijing. 
bottlenecks in further development of market mechanisms, due mainly to lack of government sector reform and an undesirable legal environment for a market economy. This indicates a need for further institutional reforms.

Using the NERI Index of Marketisation as a basis for empirical study, this chapter finds that marketisation made a significant contribution to economic growth during the period from 1997 to 2005, especially in recent years.

\section{Notes}

1 In our earlier reports, we used the Principal Component Analysis Method (PCAM) for weight determination. We found, however, that the PCAM and an equal-weighting method produce very similar results. In addition, the PCAM leads to incomparability of scores over time due to changes in weights, whereas an equal-weighting method has an advantage in providing consistent scores over time.

2 The size of government is indicated approximately by employment in public management and social organisations, which includes employment in political parties and other social organisations, however, employment in the government and the ruling party accounted for the greatest part.

3 The initial national total capital stock in 1952 is assumed to be 69 billion yuan in 1952 prices, based on the estimate of Chow (1993); also see Wang (2006). With an assumption of equal capital-output ratio, the initial capital stock is distributed to each province based on the provincial share in GDP in 1952. The depreciation rate is set at 5 per cent for the pre-reform period, and gradually increased to 9.2 per cent from 1979 to 1992.

\section{References}

China Securities Newspaper, 2006. 'The general tariff level of China will reduce to 9.8\%', China Securities Newspaper, 27 December.

Chow, G.C., 1993. 'Capital formation and economic growth in China', The Quarterly Journal of Economics, 58(3):809-42.

Fan, G. and Wang, X., 2001. NERI Index of Marketisation for China's Provinces: 2000 report (in Chinese), Economic Science Press, Beijing.

Fan, G., Wang, X. and Zhu, H., 2003. NERI Index of Marketisation for China's Provinces: 2001 report (in Chinese), Economic Science Press, Beijing.

- —, 2004. NERI Index of Marketisation for China's Provinces: 2004 report (in Chinese), Economic Science Press, Beijing.

-_, 2007. NERI Index of Marketisation for China's Provinces: 2006 report (in Chinese), Economic Science Press, Beijing.

Lucas, R.E., 1988. 'On the mechanics of economic development', Journal of Monetary Economics, 22:3-42.

National Bureau of Statistics (NBS), various years. China Statistical Yearbook (in Chinese), China Statistical Press, Beijing. 
_—, 2005b. China Compendium of Statistics: 1949-2004 (in Chinese), China Statistical Press, Beijing.

Solow, R.M., 1956. 'A contribution to the theory of economic growth', Quarterly Journal of Economics, 70:65-94.

Wang, X., 2006. 'Growth accounting after statistical revisions', in R. Garnaut and L. Song (eds), The Turning Point in China's Economic Development, Asia Pacific Press, The Australian National University, Canberra:35-52. 
Table A3.1 NERI index of marketisation for China's provinces, 1997-2005

\begin{tabular}{|c|c|c|c|c|c|c|c|c|c|}
\hline & 1997 & 1998 & 1999 & 2000 & 2001 & 2002 & 2003 & 2004 & 2005 \\
\hline Beijing & 4.786 & 4.550 & 4.567 & 4.886 & 6.171 & 6.917 & 7.498 & 8.188 & 8.619 \\
\hline Tianjin & 4.795 & 5.204 & 5.432 & 5.846 & 6.589 & 6.732 & 7.027 & 7.863 & 8.342 \\
\hline Hebei & 4.507 & 4.714 & 4.733 & 4.777 & 4.926 & 5.288 & 5.585 & 6.048 & 6.405 \\
\hline Shanxi & 2.855 & 3.078 & 3.044 & 3.058 & 3.402 & 3.928 & 4.626 & 5.130 & 5.262 \\
\hline Inner Mongolia & 3.048 & 3.499 & 3.223 & 3.318 & 3.531 & 3.998 & 4.389 & 5.119 & 5.521 \\
\hline Liaoning & 4.941 & 5.002 & 4.708 & 4.956 & 5.473 & 6.064 & 6.605 & 7.365 & 7.835 \\
\hline Jilin & 3.665 & 3.728 & 3.672 & 3.752 & 3.999 & 4.579 & 4.691 & 5.493 & 5.890 \\
\hline Heilongjiang & 2.876 & 3.486 & 3.266 & 3.472 & 3.734 & 4.089 & 4.451 & 5.046 & 5.263 \\
\hline Shanghai & 5.847 & 5.897 & 6.011 & 6.627 & 7.616 & 8.344 & 9.355 & 9.808 & 10.407 \\
\hline Jiangsu & 6.227 & 6.385 & 6.516 & 6.611 & 6.829 & 7.396 & 7.966 & 8.625 & 9.065 \\
\hline Zhejiang & 6.619 & 6.879 & 6.904 & 7.203 & 7.643 & 8.373 & 9.100 & 9.772 & 9.896 \\
\hline Anhui & 4.734 & 4.698 & 4.509 & 4.554 & 4.750 & 4.951 & 5.370 & 5.992 & 6.556 \\
\hline Fujian & 6.642 & 6.973 & 6.943 & 7.156 & 7.393 & 7.632 & 7.972 & 8.330 & 8.624 \\
\hline Jiangxi & 3.733 & 4.189 & 3.800 & 3.914 & 4.003 & 4.634 & 5.059 & 5.758 & 6.225 \\
\hline Shandong & 5.182 & 5.597 & 5.237 & 5.355 & 5.661 & 6.229 & 6.812 & 7.522 & 8.210 \\
\hline Henan & 4.025 & 4.254 & 3.893 & 3.986 & 4.136 & 4.300 & 4.889 & 5.638 & 6.198 \\
\hline Hubei & 3.718 & 4.107 & 3.783 & 3.892 & 4.248 & 4.654 & 5.468 & 6.105 & 6.652 \\
\hline Hunan & 3.709 & 3.991 & 3.658 & 3.703 & 3.939 & 4.407 & 5.032 & 6.113 & 6.546 \\
\hline Guangdong & 7.255 & 7.456 & 7.491 & 7.774 & 8.183 & 8.627 & 8.992 & 9.361 & 10.057 \\
\hline Guangxi & 3.960 & 4.021 & 3.862 & 3.854 & 3.934 & 4.750 & 5.000 & 5.415 & 5.818 \\
\hline Hainan & 5.423 & 5.311 & 5.192 & 5.215 & 5.664 & 5.094 & 5.032 & 5.411 & 5.542 \\
\hline Chongqing & 4.616 & 4.741 & 4.693 & 4.789 & 5.202 & 5.706 & 6.469 & 7.196 & 7.234 \\
\hline Sichuan & 4.525 & 4.670 & 4.406 & 4.542 & 4.999 & 5.346 & 5.855 & 6.383 & 6.860 \\
\hline Guizhou & 2.740 & 3.032 & 2.855 & 2.954 & 2.947 & 3.044 & 3.667 & 4.171 & 4.572 \\
\hline Yunnan & 3.636 & 3.894 & 3.561 & 3.688 & 3.823 & 3.797 & 4.231 & 4.813 & 5.153 \\
\hline Tibet & 0.100 & 0.150 & 0.200 & 0.250 & 0.325 & 0.625 & 0.792 & 1.555 & 2.500 \\
\hline Shaanxi & 2.792 & 3.179 & 3.220 & 3.347 & 3.369 & 3.905 & 4.109 & 4.457 & 4.797 \\
\hline Gansu & 2.832 & 3.160 & 2.951 & 2.920 & 3.044 & 3.054 & 3.323 & 3.949 & 4.445 \\
\hline Qinghai & 1.547 & 1.785 & 1.866 & 2.168 & 2.375 & 2.446 & 2.596 & 3.099 & 3.838 \\
\hline Ningxia & 1.990 & 2.367 & 2.473 & 2.558 & 2.696 & 3.238 & 4.238 & 4.564 & 4.850 \\
\hline Xinjiang & 1.474 & 1.662 & 1.879 & 2.526 & 3.183 & 3.409 & 4.264 & 4.762 & 5.024 \\
\hline Average & 4.026 & 4.247 & 4.147 & 4.311 & 4.638 & 5.018 & 5.499 & 6.098 & 6.523 \\
\hline
\end{tabular}

Note: The original data are comparable only within each of the four sub-periods (that is, 1997-99, 1999-2000, 2000-02, 2001-05), due to changes in statistical definition, modification of the index system and changes in base years. Because each sub-period's first year overlaps with the last year of the previous sub-period, this enables us to calculate the conversion factors for scores in every adjacent two sub-periods, and then recalculate the scores in all the earlier sub-periods using a nesting method. Data in this table are therefore comparable over the entire period from 1997 to 2005.

Source: Calculated from the NERI Index of Marketisation: Fan, G. and Wang, X., 2001. NERI Index of Marketisation for China's Provinces: 2000 report (in Chinese), Economic Science Press, Beijing; Fan, G., Wang, X. and Zhu, H., 2003. NERI Index of Marketisation for China's Provinces: 2001 report (in Chinese), Economic Science Press, Beijing; Fan, G., Wang, X. and Zhu, H., 2004. NERI Index of Marketisation for China's Provinces: 2004 report (in Chinese), Economic Science Press, Beijing; Fan, G., Wang, X. and Zhu, H., 2007. NERI Index of Marketisation for China's Provinces: 2006 report (in Chinese), Economic Science Press, Beijing. 


\section{Table A3.2 The structure of the NERI Index of Marketisation}

Title of the indices

The overall index of marketisation

I Government-market relations

I-1 Government allocation of resources in GDP 1

I-2 Tax and non-tax burden of farmers 2

I-3 Government intervention in enterprises 3

I-4 Non-tax burden on enterprises 4

I-5 Size of government 5

II Development of the non-state enterprise sector

II-1 Non-state share in industrial output 6

II-2 Non-state share in total investment in fixed assets $\quad 7$

II-3 Non-state share in total urban employment 8

III Development of the commodity market

III-1 Market pricing

III-1-1 Market pricing in retail sales of consumer goods 9

III-1-2 Market pricing in capital goods $\quad 10$

III-1-3 Market pricing in farm products $\quad 11$

III-2 Local trade protection $\quad 12$

IV Development of factor markets

IV-1 Marketisation of the financial sector

IV-1-1 Share of non-state financial institutions in total deposits 13

IV-1-2 Share of bank loans credited to non-state enterprises 14

IV-2 Foreign investment $\quad 15$

IV-3 Labour mobility $\quad 16$

IV-4 Development of the technology market $\quad 17$

$\mathrm{V}$ Intermediate/legal framework

V-1 Development of market intermediaries

V-1-1 Share of lawyers in local population 18

V-1-2 Share of independent accountants in local population $\quad 19$

V-2 Legal environment for businesses $\quad 20$

V-3 Protection of intellectual property rights

V-3-1 Patent applications per research and development personnel 21

V-3-2 Patents granted per research and development personnel 22

V-4 Protection of consumers' rights 23

Source: Fan, G., Wang, X. and Zhu, H., 2007. NERI Index of Marketisation for China's Provinces: 2006 report (in Chinese), Economic Science Press, Beijing. 